\title{
The Binding Nature of Administrative Instructions: An Overview
}

\author{
Susanah Naushad*
}

\section{Abstract}

Administrative instructions or administrative directions are issued by a higher authority to a lower authority directing as to how certain discretionary powers are to be exercised by the executive. Issuing such administrative instructions is relatively a modern function of administrative bodies. The mechanisms by which administrative authorities issue instructions are through letters, circulars, orders, memoranda, pamphlets, public notices, press notices and even notification in the government gazettes. Such instructions can be specific or general and mandatory or directory. If they are directory then they are not binding. In this article, the author seeks to analyse the binding nature of mandatory administrative instructions, which is vague under administrative law.

Keywords: Administrative Instructions, Constitution of India, Executive, Statutory Force, Supreme Court

\section{Introduction}

In administration, issuing of directions cannot be dispensed with. Administrative instructions fill the gaps in legislations including subordinate legislations. ${ }^{1}$ Such instructions can be specific or general and mandatory or directory. ${ }^{2}$ If they are directory, then

\footnotetext{
* Fourth Year, BA LLB, The West Bengal National University of Juridical Sciences, Kolkata, West Bengal; susanahnaushad@gmail.com.

${ }^{1}$ Sant Ram Sharma v. State of Rajasthan, A.I.R. 1967 S.C. 1910.

${ }^{2}$ I.P. MASSEY, ADMINISTRATIVE LAW 60 (Eastern Book Company, $7^{\text {th }}$ ed. 2008).
} 
they are not binding instructions. The difficulty arises as to the binding nature of mandatory administrative instruction. Administrative instructions can be differentiated from rules as the latter always have a statutory backing. Moreover, a rule can override an instruction but an instruction cannot override a rule. ${ }^{3}$ The binding nature and enforceability of an administrative instruction flows from the statute that sanctions the issuance of such instructions. An administrative instruction reflects the exercise of general administrative power; it neither has any force of law nor does it confer any right. ${ }^{4}$ Without the backing of a statute, an instruction is not binding and not enforceable by a court of law. However, this is not a settled position of law. In a series of cases, the courts have given varied decisions on this point, which at times have been contradictory. In the case of Raman and Raman Ltd. v. State of Madras, ${ }^{5}$ the court held that instructions having statutory backing are not binding and do not have the force of law. However, this position was overruled in a number of cases wherein it was held that instructions issued under legislation are binding. The apex court has given divergent opinions on this issue that has made the position regarding the binding nature of administrative instructions more ambiguous.

In this article, the author has attempted to analyse the binding nature of administrative instructions. For this purpose, the author has divided this article into three parts. The first part deals with the binding nature of administrative instructions. The second part examines the binding nature of administrative instructions having no statutory force. The third part evaluates the binding nature of administrative instructions that modify or counters a law promulgated by the legislature or a decision of the judiciary.

${ }^{3}$ M.P. Jain \& S.N. Jain, Principles of Administrative LaW- Exhaustive COMMENTARY ON THE SUBJECT (Wadhwa $\&$ Company, $6^{\text {th }}$ ed. 2007).

${ }^{4}$ V.T. Khanzode v. Reserve Bank of India, A.I.R. 1982 S.C. 917.

${ }^{5}$ A.I.R. 1959 S.C. 694. 


\section{Nature of Administrative Instructions}

Any administrative instruction which is authorized by statutory provisions and which is issued by the executive to the subordinate authority will be binding on the latter. In the case of Delux Land Organisers v. State, ${ }^{6}$ directions issued by the central government under Section 36 of the Urban Land (Ceiling and Regulation) Act 1976 was held to be binding on the state government. The state government could not issue directions which were inconsistent with the directions of the central government.

The requirement of a statutory backing is important. A direction cannot be issued to an administrative or a legislative body by a higher authority if the former is designated by a statute and the statute does not contain provisions to issue such directions. ${ }^{7}$ The reason is that the statute wanted such an authority to be free from any direction from anyone and function independently and not as a subordinate authority.

A quasi judicial body as such cannot be subjected to instructions by an administrative body even if it is subordinate to that administrative body. The reason for this is that decision making powers of the quasi judicial body should be free from the extraneous supervision of the executive. This opinion has been reinstated in a catena of cases. For example, in the case of Sirpur Paper Mills v. Commissioner of Wealth Tax, 8 the Tax Board issued an instruction under Section 13 of the Wealth Tax Act 1957 which stated that all officers shall be bound by the directions of the Board of Direct Taxes. The court was of the opinion that the instructions under Section 13 of the said Act would only apply in administrative matters and not in quasi judicial matters. Thus, a conclusion can be drawn that an administrative instruction by a superior authority to a quasi judicial authority is not binding, even if it has a statutory force.

\footnotetext{
${ }^{6}$ A.I.R. 1992 Guj. 75.

${ }^{7}$ State of Punjab \& Anr. v. Hari Krishan Sharma, A.I.R. 1966 S.C. 1081.

${ }^{8}$ A.I.R. 1970 S.C. 1520.
} 
The question of enforceability of binding instructions issued by the executive to a subordinate authority came up for consideration in Collector, Ongole v. Narra Venkateshwara. ${ }^{9}$ In this case, the District Collector had ordered acquisition of land through notifications under Section 4(1) of the Land Acquisition Act 1894. This land acquisition was challenged on the ground that the government instruction which stated that permission of the government was required if the value of the land exceeded a certain sum, was not followed. The apex court held that although administrative instructions bind the subordinates, the violation of the same does not mean that the acquisition itself is void. Therefore, the acquisition would not be cancelled but disciplinary action could be taken against the officials. The court in Fernandez v. State of Mysore, ${ }^{10}$ also stated that where government issued instructions without any statutory backing, it would still be considered binding on officers who could be penalised for not adhering to those instructions.

The position in the aforementioned case reflects the fact that despite the lack of statutory force, an instruction of the higher authority is always binding on the subordinate authority However, in the case of J.R. Raghupathy v. State of Andhra Pradesh, ${ }^{11}$ the court has departed from the above judgments. In this case, the location of the mandal headquarters was changed by a decision of the government. This decision was questioned on the ground that it was against executive instructions. The court said that these executive instructions were in the form of mere guidelines to the collector, who had to forward the proposals to the government. Hence, executive instructions were held to be not binding although it was an instruction from a superior authority, as the instructions were considered as purely directory in nature.

\footnotetext{
${ }^{9}$ (1996) 7 S.C.C. 150.

${ }^{10}$ Fernandez v. State of Mysore, A.I.R. 1967 S.C. 1753.

${ }^{11}$ (1988) 4 S.C.C. 364.
} 


\section{Administrative Instructions Having No Statutory Force}

The question as to whether an administrative instruction has a statutory force or not cannot be determined by checking whether the statutory provisions permit the administrative agency to issue such instructions. It also depends on several other considerations like the context, object, occasion of the issuance of instruction etc. ${ }^{12}$ Administrative instructions, in certain situations, are binding on third parties, while in others they are binding on government officials only against third parties who are affected by non compliance of the instructions by the officials.

Courts have held that instructions given by a statutory body under its rule making powers dealing with service matters are not considered to have statutory backing and hence are not enforceable, as such instructions are a mere declaration of policy. ${ }^{13}$ For example, in Union of India v. S.L. Abbas, ${ }^{14}$ the court held that the instruction regarding transfer of government servants, requiring husband and wife to be posted at one place, was a policy that the government normally followed but not meant to be followed always. Therefore, the lack of statutory force can be seen as the reason for the non binding nature of the administrative instructions.

In the case of Union of India v. K.P. Joseph, ${ }^{15}$ the court held that only in certain circumstances does administrative instruction confer justiciable rights. This case concerned a memorandum conferring certain benefits to ex-military servicemen for accepting reemployment. Salary would be fixed according to the memorandum though the memorandum was in the nature of administrative instruction. Since such directions contained assurances on the basis of which third party acted and such assurances were not outside the executive power, they were held to be binding.

\footnotetext{
${ }^{12}$ S.P. SATHE, AdMinistrative LAW 122 (Lexis Nexis, $7^{\text {th }}$ ed. 2004).

${ }^{13}$ Indian Airlines Corporation v. Sukhdeo Rai, A.I.R. 1971 S.C. 1828.

${ }^{14}$ Union of India \& Ors. v. S.L. Abbas, (1993) 4 S.C.C. 357.

${ }^{15}$ Union of India v. K.P. Joseph, (1973) 2 S.C.R. 752.
} 
Courts have also opined that since administrative instructions are not deemed to be law, their binding nature is extinguished and they consequently cannot be enforced in a court of law. ${ }^{16}$ However, it is also deliberated that administrative instructions with no statutory force would be binding in certain situations, like when they consist of declaration of administrative policy and are not against any statutory provision. ${ }^{17}$ Another view was expressed in the case of $V$. Balasubramaniam v. Tamil Nadu Housing Board, ${ }^{18}$ where the court held that in the absence of any statutory rules, administrative instructions would be binding and in the event of non compliance, the writ of mandamus can be issued to the executive to secure compliance with the instructions.

Despite the diverse opinions of the apex court on the binding nature of the administrative instructions, a general conclusion that flows from most of the judgments is that administrative instructions without any statutory force can be binding, based on the objective and circumstances for which the instruction is issued.

\section{Administrative Instructions that Modify or Supersede Statutory Rules or Judicial Decisions}

While the main purpose of administrative instruction is to fill the lacunae in the statutes and supplement the rules and regulations, it is often observed that such instructions directly trench upon the ambit of the legislature. This gives rise to confusion as to whether the statute will be binding or the administrative instructions. Further, many a times an administrative instruction is nullified by the enactment of a statute. There have been instances where administrative directions were found to be inconsistent with the judicial decisions on the one hand and judicial decisions that are incompatible with administrative directions on the other.

${ }^{16}$ See Fernandez v. State of Mysore, A.I.R. 1967 S.C. 1753; K. Properties Ltd. v. Calcutta Municipality, A.I.R. 1971 Cal. 488.

${ }^{17}$ SATHE, supra note 12 , at 128.

${ }^{18}$ V. Balasubramaniam v. Tamil Nadu Housing Board, (1987) 4 S.C.C. 738. 
The Supreme Court has held in a number of cases, including Jagjit Singh v. State of Punjab, ${ }^{19}$ Indian Airlines Corporation v. Sukhdeo Rai ${ }^{20}$ and Gurdial Singh Fijji v. State of Punjab21 that administrative decisions which run counter to statutory rules are not binding and their violation cannot be enforced in a court of law. Administrative decisions issued by executive authority cannot supersede a statutory provision.

The case of V.T. Khanzode v. Reserve Bank of India, ${ }^{22}$ dealt with the binding nature of the administrative instructions that modify a law promulgated by the legislature. In this case, the Reserve Bank of India laid down guidelines for the promotion of its employees. As per the regulations, the promotion could only be within the group to which the employee belonged or on the basis of seniority. Later, another circular issued by the Reserve Bank of India changed this system. In this case, the staff regulation was held not to be under the Reserve Bank of India Act 1934 and therefore was not a rule.

One case that departed from the catena of decisions relating to the non binding nature of administrative instructions that supersede statutory rules and regulations is Amitabh Srivastava v. State of Madhya Pradesh. ${ }^{23}$ In this case, the appellant had applied for admission in a medical college for which the qualifying mark was prescribed by the Rules Relating to Admissions to Medical Colleges in Madhya Pradesh 1979. The appellant failed to qualify on the basis of these rules. Subsequently, the minimum aggregate of qualifying marks required for admission was reduced by an executive order on the basis of which he became eligible. However, the medical College Board still refused to grant admission to the appellant. The Supreme Court allowed the admission by enforcing the administrative instruction as against the rules. This controversial decision preferred an administrative instruction over a statute.

\footnotetext{
${ }^{19}$ Jagjit Singh v. State of Punjab, (1978) 2 S.C.C. 196.

${ }^{20}$ Indian Airlines Corporation v. Sukhdeo Rai, A.I.R. 1971 S.C. 1828.

${ }^{21}$ Gurdial Singh Fijji v. State of Punjab, (1979) 2 S.C.C. 368.

${ }^{22}$ V.T. Khanzode v. Reserve Bank of India, A.I.R. 1982 S.C. 917.

${ }^{23}$ Amitabh Srivastava v. State of Madhya Pradesh, (1982) 1 S.C.C. 514.
} 
This position of the Supreme Court has been reversed by subsequent judgments. In C.L. Verma v. State of Madhya Pradesh, ${ }^{24}$ wherein a government notification was struck down as ultra vires a statutory rule, the Supreme Court held that though the administrative instructions can supplement a statute, it cannot run contrary to statutory provisions or whittle down their effect.

The courts have taken contradictory views in relation to the binding nature of administrative instructions. In Union of India $\mathrm{v}$. Tulsiram Pate 25 the court held that such interpretations only reflect the opinion of the government and cannot be binding on the courts, as executive directions stand on a lower pedestal than a statute. Juxtaposed to this view, in Dr. Mukhtiar Chand \& Ors. v. State of Punjab, ${ }^{26}$ a clarificatory notification issued by the Central Council for Indian Medicine was considered by the court while interpreting a term referred to in the Indian Medicine Central Council Act 1970. An administrative instruction will not be binding if it encroaches upon the areas covered by judicial orders. ${ }^{27}$ Therefore, an executive direction declaring an earlier decision of a court as invalid will not be binding.

\section{Conclusion}

There is no clarity regarding the binding nature of administrative instructions. The varied decisions of the Supreme Court in this regard have only added to the confusion. Therefore, the binding nature of administrative instructions is complicated and ambiguous. Nevertheless, it can be concluded from a majority of the decisions on administrative instructions that the binding value of such instructions is dependent on its source. If an instruction is backed by a statute, it will be binding as long as it does not violate any fundamental rights under the Constitution. If an instruction has no legal backing but it does not explicitly go against any law or attempt to modify or counter it, it will still be binding.

\footnotetext{
${ }^{24}$ C.L. Verma v. State of Madhya Pradesh, A.I.R. 1990 S.C. 463.

${ }^{25}$ Union of India v. Tulsiram Patel, (1985) 3 S.C.C. 398.

${ }^{26}$ Dr. Mukhtiar Chand \& Ors. v. State of Punjab, (1998) 7 S.C.C. 579.

${ }^{27}$ Anil Ratan Sarkar v. State of West Bengal, (2001) 5 S.C.C. 327 at 337.
} 